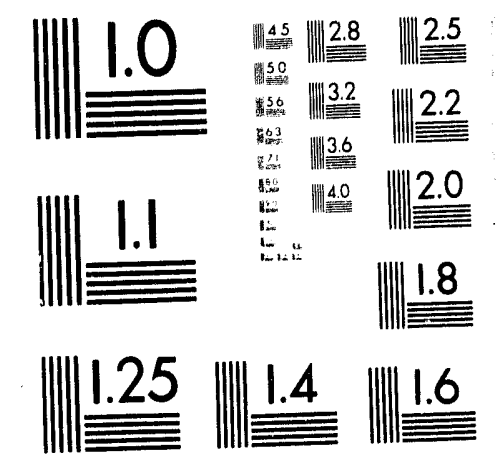



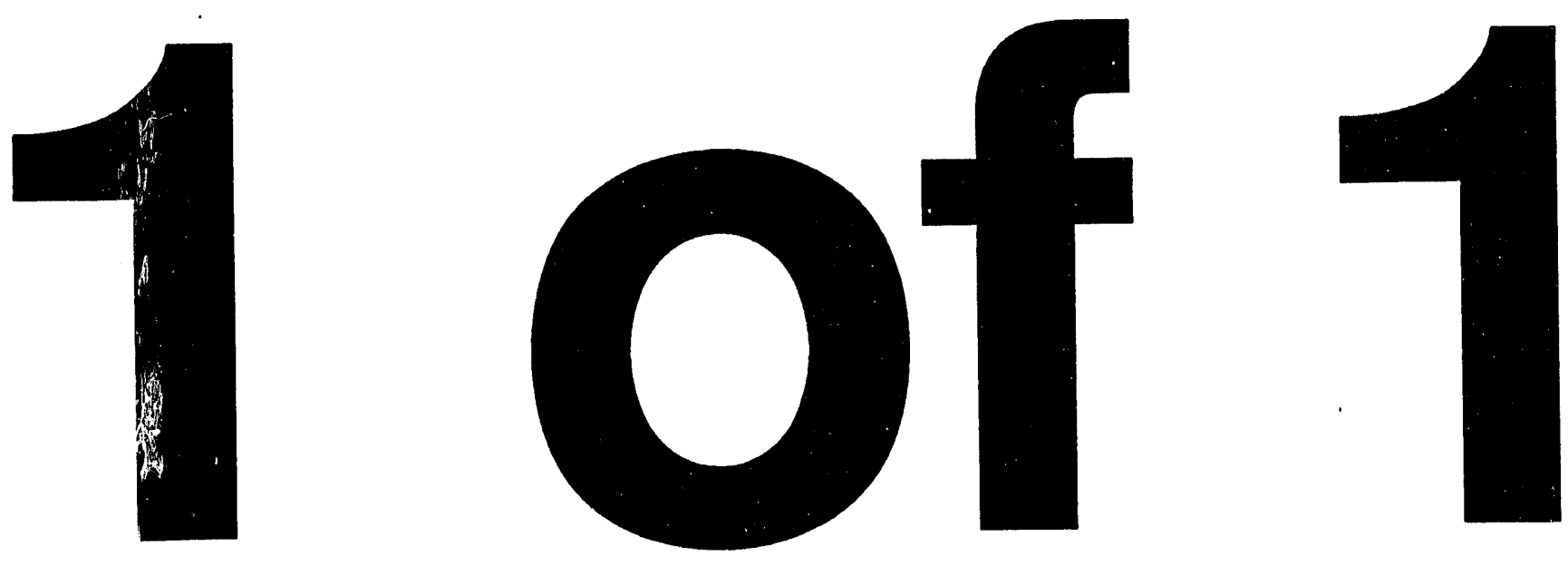


\section{Conf $930405--44$}

UCRL-JC-114157

PREPRINT

Using the Rule of Mixtures to Examine the Hardness of $\mathrm{Cu} / \mathrm{Cu}-\mathrm{Zr}$ Multilayers

\section{OCT 141993 \\ OSTI}

T. P. Weihs, T. W. Barbee, Jr. and M. A. Wa1I

This paper was prepared for submittal to the

1 j93 Materials Research Society Spring Meeting Symposium M-1, San Francisco, CA, April 12-16, 1993.

June 1993

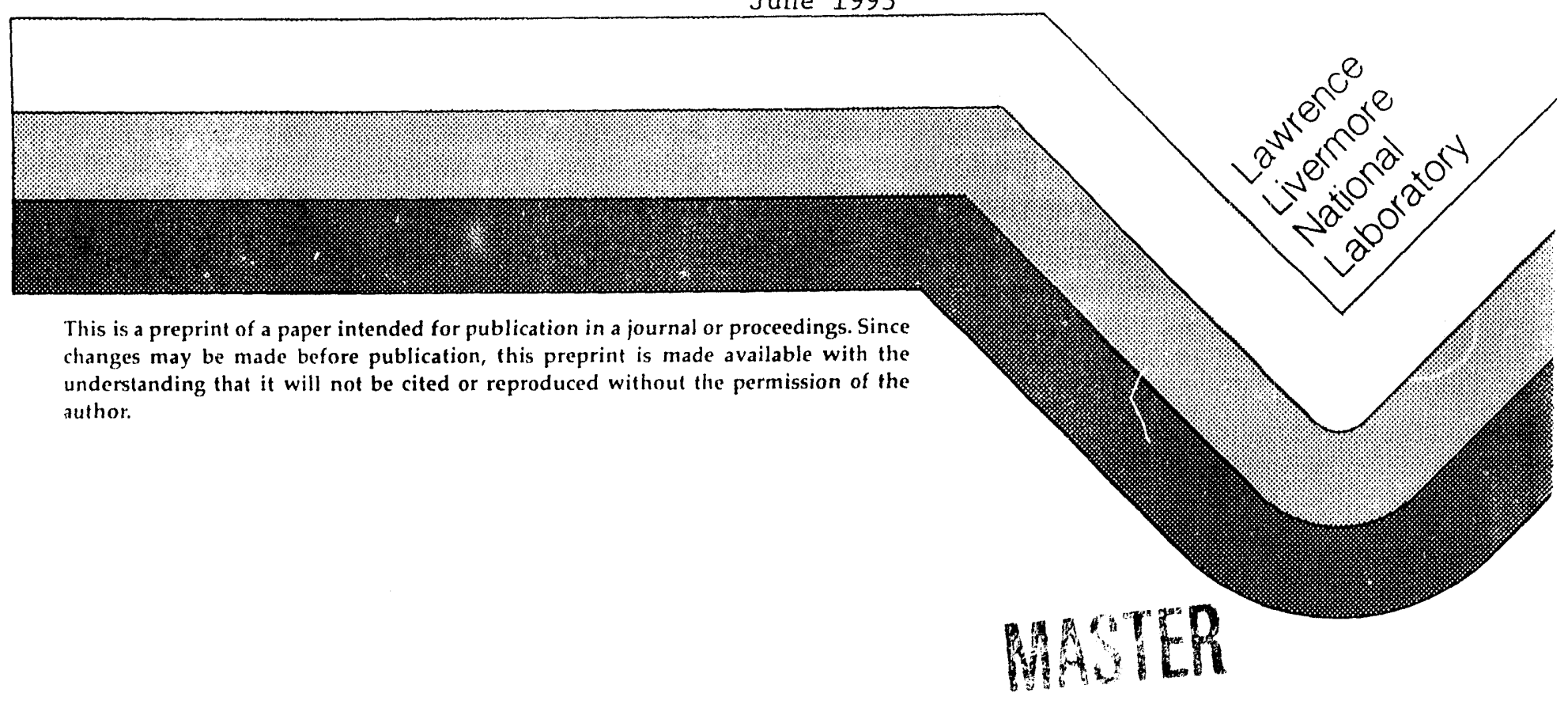

$d s$ 


\section{DISCLAIMER}

This docameat was prepared as an account of work spoasored by an useacy of the tinited States Government. Feither the Liaited States Goverament nor the Laiversity of California nor any of their employees. makes any warranty, express or implied. of sssumes an! legal lisbility or responsibility for the scceracy. completenesx. or usefulness of any information. apparatus, produch or process disclosed. or represeats that its use nonld not infringe privately onned rights. Refereace berein to any sperific commercial products process, or service by trade anme, trodemerk. manufacturer. or otberwise, does wot mecessarily constitute or imply its eadorsement, recommendation. or tavoring by the Laited Ststes Goverameat or the Cairersity of Califorala The views and opinions of anthors expressed berein do eol secessarily state or reflect those of the United States Government or the Uaiversity of Califormian and shall oot be ased for advertising or product endorsement purposes. 


\title{
USING THE RULE OF MIXTURES TO EXAMINE THE HARDNESS OF $\mathrm{Cu} / \mathrm{Cu}-\mathrm{Zr}$ MULTILAYERS
}

\author{
T.P.Weihs, T.W. Barbee, Jr., and M.A. Wall, Lawrence Livermore National Laboratory, \\ Livermore, CA 94550
}

\begin{abstract}
$\mathrm{Cu} / \mathrm{Cu}-\mathrm{Zr}$ multilayer foils were fabricated and indented to determine the degree to which multilayer hardness is enhanced by increasing the volume fraction of the harder phase. Using sputter deposition and thermal processing a series of foils was fabricated in which the thicknesses of the $\mathrm{Cu}$ layers remained fixed while the thicknesses of the alternate $\mathrm{Cu}-\mathrm{Zr}$ layers varied. These samples were then indented both parallel and normal to their layering. In general, hardness increased as the volume fraction of the harder $\mathrm{Cu}-\mathrm{Zr}$ phase rose. When the films were loaded parallel to their layering, the measured hardnesses were higher and the dependencies on volume fraction of the $\mathrm{Cu}-\mathrm{Zr}$ phase were stronger than when the films were loaded normal to their layering. These results agree with predictions based on isostress and isostrain theories. The relationships between hardness and volume fraction are used to compare the hardnesses of the $\mathrm{Cu}-\mathrm{Zr}$ phases: amorphous $\mathrm{Cu}-\mathrm{Zr}, \mathrm{Cu}_{51} \mathrm{Zr}_{14}$ and $\mathrm{Cu}_{9} \mathrm{Zr}_{2}$, and to show that the hardness of the textured, as-deposited $\mathrm{Zr}$ layers is highly anisotropic .
\end{abstract}

\section{INTRODUCTION}

The ability to harden a multilayered film by decreasing its bilayer thicknesses has been studied extensively [1-4]. Many researchers have reported substantial increases in hardness for a wide variety of thicknesses and a wide variety of materials. However, throughout this work, little attention has been given to the volume fraction of the different materials in a multilayer system. We suggest that volume fraction deserves greater consideration as multilayered films are being developed for protective coating applications. This geometrical parameter will be an important design tool as engineers attempt to optimize several film properties such as wear resistance, fracture resistance and corrosion resistance in a single multilayered coating. Here, we determine the change in hardness of $\mathrm{Cu} / \mathrm{Cu}-\mathrm{Zr}$ multilayer foils as the volume fraction of the harder $\mathrm{Cu}-\mathrm{Zr}$ phase is increased. To isolate the effect of volume fraction from other hardening effects, the foils were deposited and then processed to produce a set of specimens in which the thickness of the softer $\mathrm{Cu}$ layers remained fixed, while the thickness of the harder $\mathrm{Cu}-\mathrm{Zr}$ layers increased. Under these conditions, the volume fraction of the stronger $\mathrm{Cu}-\mathrm{Zr}$ phase was increased without enhancing the hardness of either individual layer by decreasing its thickness. In this case, any enhancements in the multilayer's hardness are due to an increase in the volume fraction of the harder $\mathrm{Cu}-\mathrm{Zr}$ phase and not a reduction in layer thickness.

\section{THEORY}

When one compresses a layered composite normal to its layering, isostress conditions exist, and the weakest layer determines the yield load of the composite [5]. In contrast, when a layered composite is compressed parallel to its layering, isostrain conditions exist and the volume fraction and the flow behavior of each layer determine the deformation of the composite [5]. If similar loading conditions exist during the indentation of multilayers, then the foil's hardness, $\mathrm{H}$, would equal the hardness of the weakest layer when indenting normal to the layering

$$
\mathrm{H}=\mathrm{H}_{\mathrm{A}}
$$

and it would follow the rule of mixtures when indenting parallel to the layering,

$$
\mathrm{H}=\mathrm{X}_{\mathrm{A}}{ }^{*} \mathrm{H}_{\mathrm{A}}+\mathrm{X}_{\mathrm{B}}{ }^{*} \mathrm{H}_{\mathrm{B}}
$$

where $X_{A}$ and $X_{B}$ are volume fractions of layers $A$ and $B$, and $H_{A}$ and $H_{B}$ are their individual layer hardnesses. The deformation under pointed or rounded indenters, however, is radial in nature and not uniaxial [6]. Pure isostress and pure isostrain conditions do not exist during such tests. Consequently, a multilayered foil will be harder than its weakest layer when 
indenting normal to its layering, and it will be softer than the rule of mixtures suggests when indenting parallel to its layering. The goal here is to show that some rule of mixtures, in which volume fraction and layer hardness are considered, can be applied to both "isostress" and "isostrain" indentations of multilayered foils. The strength of the dependence on volume fraction will simply vary with the loading geometry.

We begin by defining the simple relation between volume fraction and layer thickness for a multilayer of alternate layers of $\mathrm{A}$ and $\mathrm{B}$. The volume fractions, $\mathrm{X}_{\mathrm{A}}$ and $\mathrm{X}_{\mathrm{B}}$, are given by

$$
X_{A}=t_{A} /\left(t_{A}+t_{B}\right) \text { and } \quad X_{B}=t_{B} /\left(t_{A}+t_{B}\right)
$$

where $t_{A}$ and $t_{B}$ are the thicknesses of layer $A$ and $B$. Note that one can not change the volume fraction without changing the thickness of at least one of the two layers. Next, we consider the relationship between a layer's hardness and its thickness,

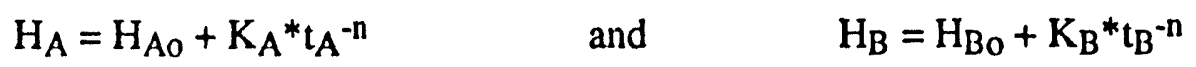

In Equations (5) and (6), $\mathrm{H}_{\mathrm{Ao}}$ and $\mathrm{H}_{\mathrm{Bo}}$ are constant terms that do not scale with layer thickness. They depend only on the resistance to deformation that is offered by the phase itself in an infinitely thick layer or grain. $\mathrm{K}_{\mathrm{A}}{ }^{*} \mathrm{t}^{-\mathrm{n}}$ and $\mathrm{K}_{\mathrm{B}}{ }^{*} \mathrm{t}^{-\mathrm{n}}$ account for the hardening that is produced by the reduction in layer thickness. $\mathrm{K}_{\mathrm{A}}$ and $\mathrm{K}_{\mathrm{B}}$ are constants, and $\mathrm{n}$ varies from 0.5 for Hall-Petch type strengthening [7] to 1.0 for a strengthening mechanism such as modulus hardening [8]. Combining Equations (5) and (6) into the standard rule of mixtures [5] in Equation (2) yields

$$
\text { or } \begin{aligned}
H & =X_{A^{*}}\left(H^{0} A+K_{A}^{*} t_{A}^{-n}\right)+X_{B}^{*}\left(H^{0} B+K_{B}{ }^{*} t_{B}^{-n}\right) \\
H & =\left(H^{0} A+K_{A}^{*} t_{A}^{-n}\right)+X_{B}{ }^{*}\left[\left(H^{0}{ }_{B}+K_{B}{ }^{*} t_{B}-n\right)-\left(H^{0} A^{-n}+K_{A}^{*} t_{A}{ }^{-n}\right)\right]
\end{aligned}
$$

To assess the dependence of hardness on the volume fraction of each phase, we hold the thickness of the softer $(\mathrm{Cu})$ A layer constant and increase the thickness of the harder $(\mathrm{Cu}-\mathrm{Zr}) \mathrm{B}$ layer. Under these conditions, the hardness of layer A will remain constant (Equation (5)) while the hardness of layer $B$ will decrease (Equation (6)). However, the decrease in $\mathrm{H}_{B}$ should be small because the amorphous or intermetallic $\mathrm{Cu}-\mathrm{Zr}$ phases in the $\mathrm{B}$ layers are inherently hard, $[9,10]$ and layer thickness should not affect their resistance to plastic deformation significantly. Based on these predictions, the three separate terms in parenthesis in Equation (8) will be relatively constant, and the $\mathrm{Cu} / \mathrm{Cu}-\mathrm{Zr}$ multilayer hardness, $H$, should vary linearly with $\mathrm{X}_{\mathrm{B}}$. Any enhancements in the hardness of the $\mathrm{Cu} / \mathrm{Cu}-\mathrm{Zr}$ foils as $\mathrm{X}_{\mathrm{B}}$ and $t_{\mathrm{B}}$ increase will be due solely to a change in the volume fraction of $\mathrm{Cu}-\mathrm{Zr}$ and not a reduction in the thickness of either layer.

\section{EXPERIMENTAL PROCEDURES}

A series of $\mathrm{Cu} / \mathrm{Cu}-\mathrm{Zr}$ multilayered foils was produced by depositing and processing alternate layers of $\mathrm{Cu}$ and $\mathrm{Zr}$. The foils were magnetron sputter cleposited onto $3.0 \mathrm{in}$ and $6.0 \mathrm{in}(100) \mathrm{Si}$ wafers at powers ranging from $41 \mathrm{~W}$ to $645 \mathrm{~W}$. After deposition, the multilayers were removed from their substrates and cut into specimens with $6 \mathrm{~m} / \mathrm{m}$ diameters. Since the as-deposited foils were approximately $26 \mu \mathrm{m}$ thick, the specimens were easily handled as free-standing samples. The as-deposited layered structure of the $\mathrm{Cu} / \mathrm{Zr}$ samples is shown in Figure 1(a). The Cu layers are polycrystalline, and the width of the $\mathrm{Cu}$ grains scale with their layer thickness. The $\mathrm{Zr}$ layers are also polycrystalline, but some solid state amorphization (SSA) [11] occurs in these layers during deposition and can be easily observed at higher magnifications. Isochronal and isothermal DSC scans were used to thermally process these multilayers and thereby change both the cornposition and the structure of the thinner $\mathrm{Zr}$ layers. In all such scans, the $6 \mathrm{~mm}$ specimens were crimped in $\mathrm{Cu}$ pans and were heated in a DSC chamber which was purged continuously with Ar. Data for isochronal scans of four sample sets is shown in Figure 2. The three exotherms that are clearly visible correspond to the transformation of a fraction of each $\mathrm{Cu}$ layer and all of each $\mathrm{Zr}$ layer into three different phases: an amorphous $\mathrm{Cu}-\mathrm{Zr}$ alloy $(\mathrm{aCu}-\mathrm{Zr})$, the crystalline alloy $\mathrm{Cu}_{51} \mathrm{Zr}_{14}$, and finally the stable crystalline alloy $\mathrm{Cu}_{9} \mathrm{Zr}_{2}$. After determining the temperatures at which each phase formed, the samples w'ere scanned to those temperatures and then quenched to produce two new layered structures: $\mathrm{Cu} / \mathrm{aCu}-\mathrm{Zr}$ and $\mathrm{Cu} / \mathrm{Cu}_{51} \mathrm{Zr}_{14}$. The 
thicknesses of the $\mathrm{Cu}$ and $\mathrm{Cu}-\mathrm{Zr}$ layers are based on reported compositions of $\mathrm{aCu}-\mathrm{Zr}[12]$ and $\mathrm{Cu}_{51} \mathrm{Zr}_{14}$ [13], and are listed in Table 1 along with the as-deposited $\mathrm{Cu}$ and $\mathrm{Zr}$ layer thicknesses.

Note that the $\mathrm{Cu}$ layer thicknesses are relatively constant in the processed specimens. Since Reactions 1 and 2 overlap in Figure 2, some foils were isothermally annealed at $310^{\circ} \mathrm{C}$ for

Table 1: Layer and Film Thicknesses, for As-Deposited and Processed Samples

\begin{tabular}{|c|c|c|c|c|c|c|c|c|}
\hline & & $A s-D$ & sited & Post $\mathrm{F}$ & tion 1 & Post & action 2 & \\
\hline $\begin{array}{c}\text { Sample } \\
\text { Set }\end{array}$ & $\% \mathrm{Zr}$ & $\begin{array}{l}\mathrm{Cu} \\
(\AA)\end{array}$ & $\begin{array}{l}\mathrm{Zr} \\
(\AA)\end{array}$ & $\begin{array}{l}\mathrm{Cu} \\
(\AA)\end{array}$ & $\begin{array}{c}\mathrm{aCu}-\mathrm{Zr} \\
(\AA)\end{array}$ & $\begin{array}{l}\mathrm{Cu} \\
(\AA)\end{array}$ & $\begin{array}{c}\mathrm{Cu}_{51} \mathrm{Zr}_{14} \\
(\mathrm{~A})\end{array}$ & $\begin{array}{l}\text { Film } \\
(\mu \mathrm{m})\end{array}$ \\
\hline$\overline{\bar{A}}$ & 3.09 & 387.3 & 24.5 & 350.2 & $\overline{56.8}$ & $\overline{342.2}$ & 68.2 & 25.7 \\
\hline$B$ & 5.52 & 424.9 & 49.2 & 350.4 & 114.1 & 334.4 & 136.9 & 26.5 \\
\hline $\mathrm{C}$ & 7.38 & 467.4 & 73.9 & 355.6 & 171.2 & 331.7 & 205.5 & 27.1 \\
\hline D & 9.00 & 502.5 & 98.5 & 353.4 & 228.4 & 321.4 & 274.1 & 27.4 \\
\hline
\end{tabular}
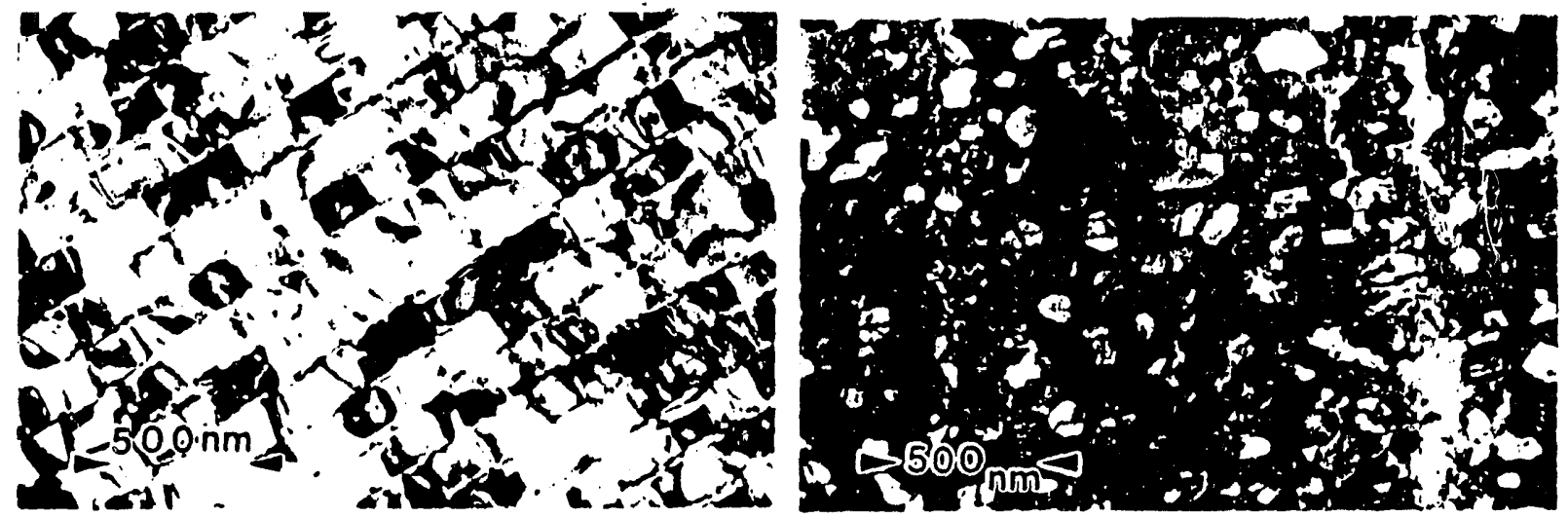

Figure 1: The TEM images show polycrystalline $\mathrm{Cu}$ layered with polycrystalline $\mathrm{Zr}$ in (a) and $\mathrm{Cu}$ grains imbedded in $\mathrm{Cu}_{9} \mathrm{Zr}_{2}$ grains in (b).

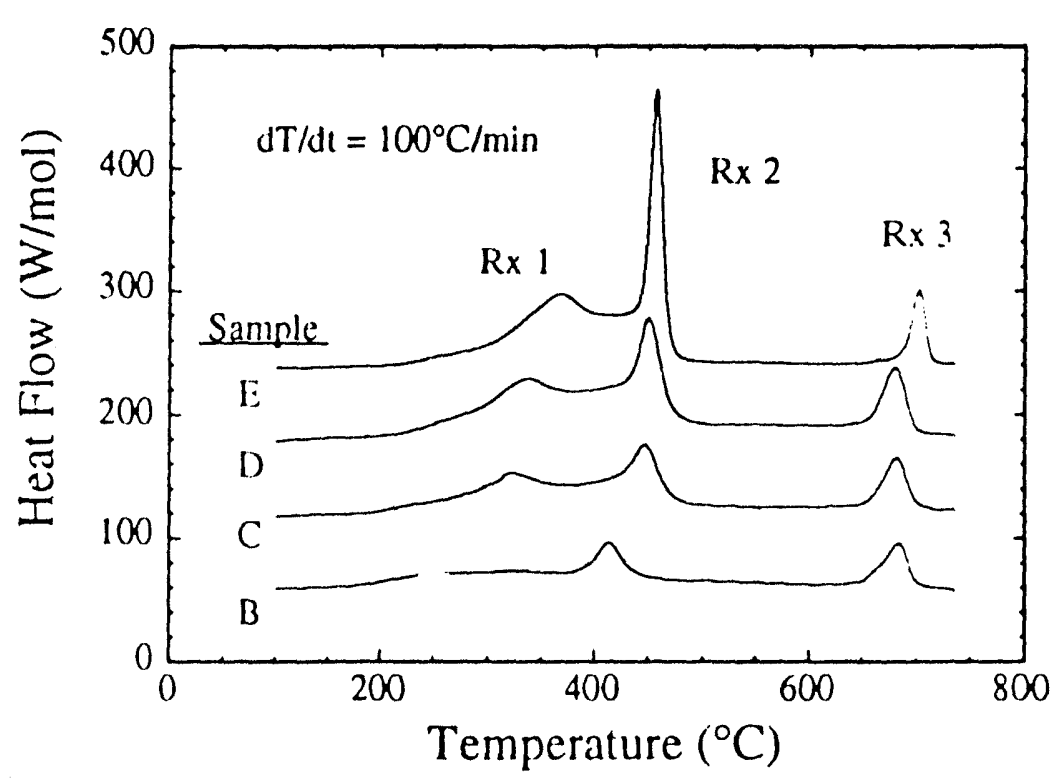

$200 \mathrm{~min}$ to insure completion of the SSA without nucleation of the crystalline phase, $\mathrm{Cu}_{51} \mathrm{Zr}_{14}$. However, these specimens were only indented on edge since their surfaces were partially oxidized after such long anneals. During the third reaction in Figure 2, the layering broke down and the $\mathrm{Cu} 9 \mathrm{Zr} 2$ grains grew significantly, encompassing the smaller $\mathrm{Cu}$ grains. This final structure is shown in a TEM micrograph in Figure 1(b). A detailed analysis of the thermal processing of the $\mathrm{Cu} / \mathrm{Cu}-\mathrm{Zr}$ foils is given in reference [14].

Figure 2: Isochronal DSC scans of the 4 Samples listed in Table 1. The heating rate was $100^{\circ} \mathrm{C} / \mathrm{min}$.

The different phases in the processed films were decermined using X-ray diffraction (XRD) and transmission electron microscopy (TEM). The $\mathrm{Cu}$ and the $\mathrm{Zr}$ layers were highly textured as deposited. The stable $\mathrm{Cu}$ phase retained this texture during all thermal processing. Low-angle $X R \cap$ and rence-certinnal TF.M confirmed the nresence and the uniformity of layering within 
samples that were heated up to $650^{\circ} \mathrm{C}$. For mechanical characterizations, $6 \mathrm{~mm}$ disks were glued to glass substrates to measure hardnesses normal to the layers. Similar specimens were mounted on edge in epoxy and then mechanically polished to measure hardnesses parallel to the layers. For each sample set, four different specimens were considered - $\mathrm{Cu} / \mathrm{Zr}, \mathrm{Cu} / \mathrm{aCu}-\mathrm{Zr}$, $\mathrm{Cu} / \mathrm{Cu}_{51} \mathrm{Zr}_{14}$ and $\mathrm{Cu}$ in $\mathrm{Cu}_{9} \mathrm{Zr}_{2}$. All hardness measurements were performed at room temperature with a Vickers Hardness Tester and a $10 \mathrm{~g}$ load.

\section{RESULTS AND DISCUSSION}

After the $\mathrm{Zr}$ in the multilayers reacted with the surrounding $\mathrm{Cu}$ and formed amorphous $\mathrm{Cu}-\mathrm{Zr}$, and then crystalline $\mathrm{Cu}_{51} \mathrm{Zr}_{14}$, the hardness of each sample increased as shown in Figure 3. The percentage increase was largest for Sample $D$ which contains the largest volume fraction of the $\mathrm{Cu}-\mathrm{Zr}$ phase. When specimens were scanned above $650^{\circ} \mathrm{C}$, the stable phase, $\mathrm{Cu}_{9} \mathrm{Zr}_{2}$, nucleated, the layered structure broke down, and the measured hardnesses decreased significantly. These large decreases are attributed to the loss of the layered structure.

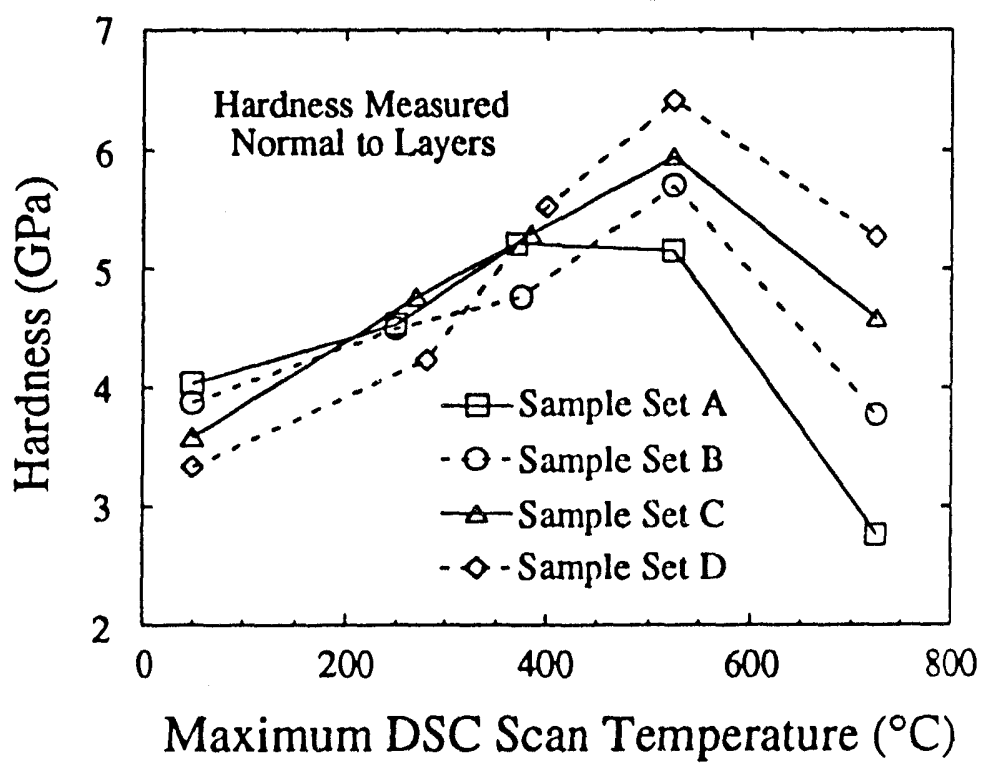

Figure 3: The hardness of each specimen is plotted versus the temperature to which it was scanned in a DSC.
In Figures 4 and 5 , the hardnesses of the $\mathrm{Cu}-\mathrm{Zr}$ foils are plotted as a function of volume fraction for both loading geometries. The data in Figure 4 is taken from indentations made normal to the foil layering and the data in Figure 5 is taken from indentations made parallel to the foil layering. The results for the four individual foil structures - $\mathrm{Cu} / \mathrm{Zr}, \mathrm{Cu} / \mathrm{aCu}$ $\mathrm{Zr}, \mathrm{Cu} / \mathrm{Cu}_{51} \mathrm{Zr}_{15}$, and $\mathrm{Cu}$ in $\mathrm{Cu}_{9} \mathrm{Zr}_{2}$ will be reviewed first, and then the general trends of the collective data set shall be considered.

For the as-deposited foils with the $\mathrm{Cu} / \mathrm{Zr}$ structure, the dependence of hardness on volume fraction differs dramatically between the two loading geometries. As the volume fraction of $\mathrm{Zr}$ rises, the as-deposited hardnesses decrease in Figure 4 and increase in Figure 5. The opposite dependence is attributed to the texturing of the $\mathrm{Zr}$ and the nature of deformation in hexagonal close-packed (HCP) crystals [9]. After deposition, the $\mathrm{Zr}$ in the multilayered foils is highly textured with its basal planes lying in the plane of the foil. When $\mathrm{HCP}$ crystals such as $\mathrm{Zr}$ are indented, hardness varies considerably with crystallographic orientation. The hardness measured on the basal plane of $\mathrm{Ti} \mathrm{[15],} \mathrm{Co} \mathrm{[16],} \operatorname{Re}[17]$ or $\mathrm{Zn} \mathrm{[15]}$ differs from the hardness measured on $\{1120\}$ planes of these crystals by a factor of up to 5 . The direction of this difference, whether 1 to 5 or 5 to 1 , can vary as well. We suggest that the highly textured $\mathrm{Zr}$ layers show similar anisotropy. When the as-deposited foils are indented normal to their layering, the $\mathrm{Zr}$ deforms more easily than the $\mathrm{Cu}$ and therefore reduces the foil hardness as its volume fraction increases in Figure 4. When the as-deposited foils are indented parallel to their layering, the $\mathrm{Zr}$ deforms less easily than the $\mathrm{Cu}$ and thereby raises the foil hardness as its volume fraction increases in Figure 5. For Sample Set D with 9.0 at\% $\mathrm{Zr}$, this anisotropy produces a 33\% difference between the hardnesses measured in the two loading geometries. Such anisotropies must be considered when designing multilayered coatings.

After the $\mathrm{Cu}-\mathrm{Zr}$ multilayers were processed to obtain the $\mathrm{Cu} / \mathrm{aCu}-\mathrm{Zr}$ and the $\mathrm{Cu} / \mathrm{Cu}_{51} \mathrm{Zr}_{14}$ structures, with constant $\mathrm{Cu}$ layer thicknesses, the measured hardnesses showed a consistent increase with the volume fraction of the $\mathrm{Cu}-\mathrm{Zr}$ phase under both loading geometries. In Figure 
4, the dependence of hardness on volume fraction is weak for this "isostress" type of loading, particularly for the $\mathrm{Cu} / \mathrm{aCu}-\mathrm{Zr}$ foils. In Figure 5, the dependence is much stronger as the loading approaches an isostrain type of geometry. For the $\mathrm{Cu} / \mathrm{Cu}_{51} \mathrm{Zr}_{14}$ foils indented parallel to their layering, hardness increases $150 \%$ as the volume fraction of $\mathrm{Cu}-\mathrm{Zr}$ varies from 0.0 to 1.0 in Figure 5. While this percentage increase could be larger under pure isostrain conditions, it does imply a strong dependence of multilayer hardness on volume fraction. It is important to remember that for these specimens, all of the increases in hardness are attributed to a change in volume fraction and not to a reduction in layer thickness. According to Equations (5) and (6), the individual $\mathrm{Cu}$ layers should have a constant hardness since their thicknesses does not vary. The individual $\mathrm{Cu}-\mathrm{Zr}$ layers could actually decrease in hardness because their thicknesses quadruple. According to Equation (8), the thickening of the $\mathrm{Cu}-\mathrm{Zr}$ layers could cause the positive slopes in Figures 4 and 5 to decrease as $\mathrm{X}_{\mathrm{Cu}-\mathrm{Zr}}$ increases. The lack of any appreciable decreases of slopes in either figure suggests that the hardnesses of $\mathrm{aCu}-\mathrm{Zr}$ and $\mathrm{Cu}_{51} \mathrm{Zr}_{14}$ are not strongly dependent on their layer thicknesses.

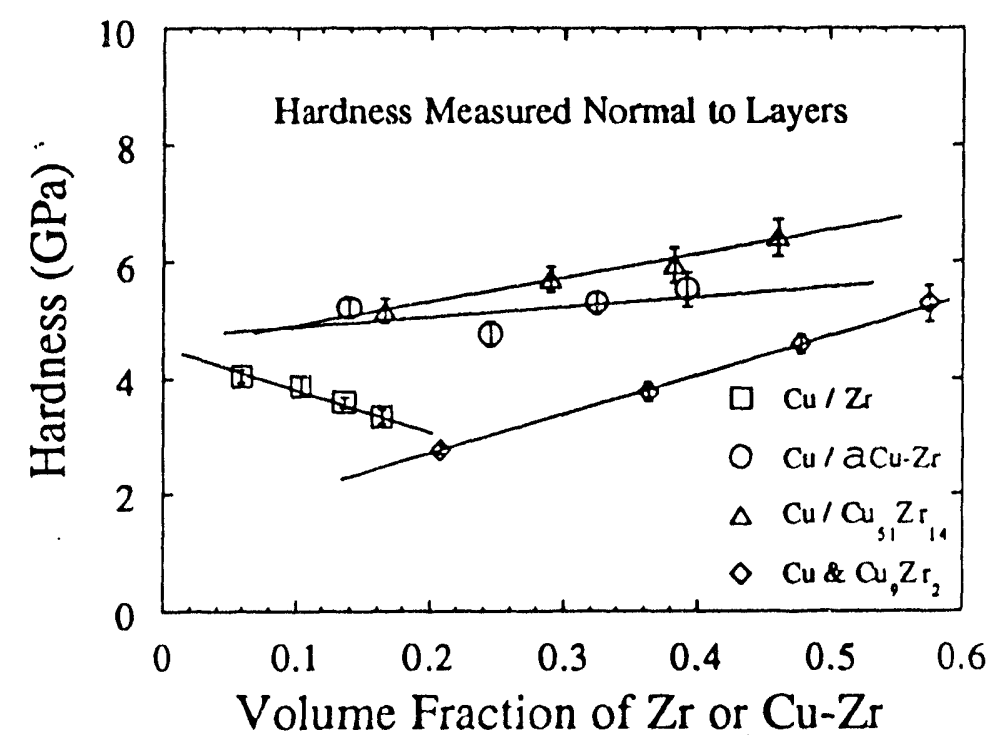

Figure 4: Hardness of $\mathrm{Cu}-\mathrm{Zr}$ multilayer foils measured normal to their layering with a $10 \mathrm{~g}$ load.

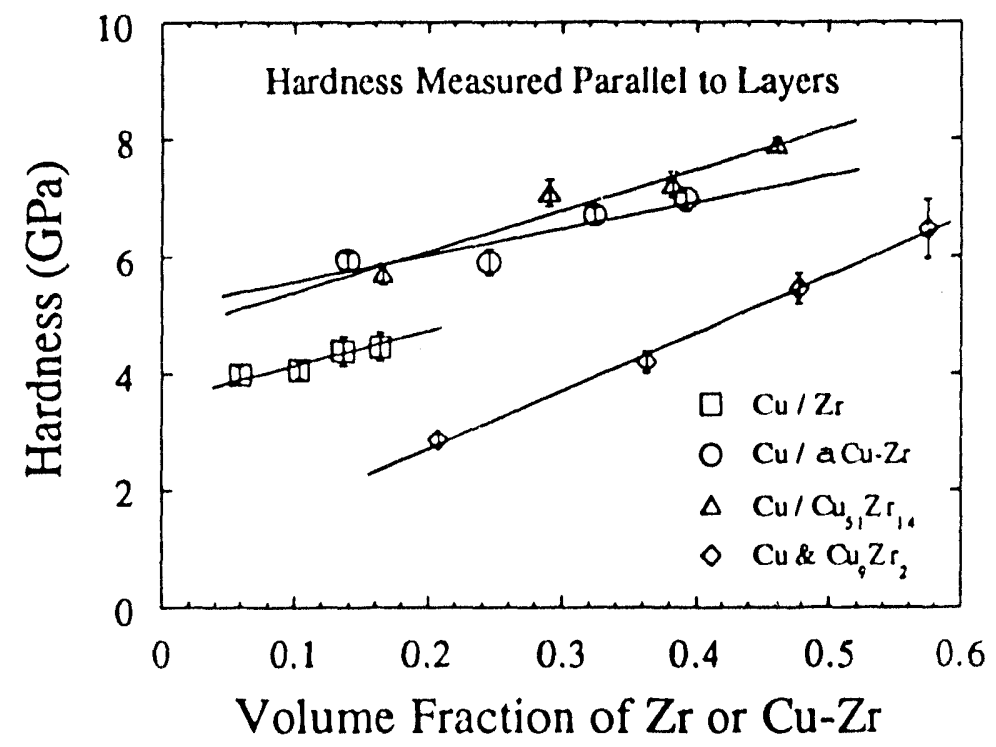

Figure 5: Hardness of $\mathrm{Cu}-\mathrm{Zr}$ multilayer foils measured parallel to their layering with a $10 \mathrm{~g}$ load.
The final data set consists of specimens with clumps of small $\mathrm{Cu}$ grains embedded in larger $\mathrm{Cu}_{9} \mathrm{Zr}_{2}$ grains (Figure 1(b)). These non-layered, particle-like composite foils are generally softer than the corresponding layered structures. Their hardness data produce the best linear fit of all the specimen sets in Figure 4 and 5 and is readily described by the simple rule of mixtures in Equations (2). However, the foils are not isotropic since hardness varies more rapidly with $\mathrm{Cu}-\mathrm{Zr}$ volume fraction in Figure 5 than in Figure 4. As $\mathrm{X}_{\mathrm{Cu}-\mathrm{Zr}}$ increases from 0.0 to 0.6 in Figure 5, the hardness of the foils increases by a factor of 8 . Using the extrapolated values at $\mathrm{X}_{\mathrm{Cu}-\mathrm{Zr}}=1.0$ in Figure 5, the hardness of $\mathrm{Cu}_{9} \mathrm{Zr}_{2}$ $(10.6 \mathrm{GPa})$ is only $10 \%$ less than that estimated for $\mathrm{Cu}_{51} \mathrm{Zr}_{14}(11.7 \mathrm{GPa})$ at $\mathrm{X}_{\mathrm{Cu}-\mathrm{Zr}}$ $=1.0$. This $10 \%$ difference matches the percentage difference measured on bulk samples [10] almost exactly. The hardness of the $\mathrm{Cu}$ phase, measured at $\mathrm{X}_{\mathrm{Cu}-\mathrm{Zr}}=0.0$, appears to decrease significantly after the final reaction and the breakdown of layering. Some of this decrease could be attributed to the stacking of the $\mathrm{Cu}$ grains that is seen in Figure 1(b). If the stacking enables dislocations to move readily from one $\mathrm{Cu}$ grain to the next, then the effective $\mathrm{Cu}$ grain size is much larger than the grain size seen in the layered foils (Figure 1(a), and the effective hardness of the Cu volume decreases. 
Referring now to the processed specimens in general, the average foil hardness increases as the volume fraction of the harder $\mathrm{Cu}-\mathrm{Zr}$ phase rises in Figures 4 and 5 . This result shows no evidence of a purely isostress condition during multilayer indentation. The softer phase in a bilayered foil does not strictly determine the multilayer hardness, even when indenting normal to the layering. The results do show that the hardness of a multilayer foil follows a general rule of mixtures that accounts for the hardness and the volume fraction of each phase. The dependence of hardness on volume fraction is stronger when indenting parallel to the foil layering than when indenting normal to the foil layering for all of the processed foils. This difference is shown by the sharper rise of data in Figure 5 than in Figure 4, and it agrees with earlier predictions. If a modified rule of mixtures can be determined for several $\mathrm{Cu}$ layer thicknesses, volume fractions and loading geometries, then one could begin 10 predict multilayer hardnesses for any combination of layer thicknesses, volume fractions or loading geometries.

\section{CONCLUSIONS}

The hardness of $\mathrm{Cu} / \mathrm{Cu}-\mathrm{Zr}$ multilayered foils increases as the volume fraction of the $\mathrm{Cu}-\mathrm{Zr}$ layers rises. This dependence can be modeled using a modified rule of mixtures. When the foils are loaded parallel to their layering, the foils are harder and depend more strongly on volume fraction than when the foils are loaded normal to their layering. This result agrees with predictions based on isostress and isostrain theories, and it suggests that one can predict the hardness of multilayered foils using volume fractions, loading genmetry and a modified rule of mixtures. Using the linear variations of the measured data, the hardness of the individual phases - $\mathrm{Cu}, \mathrm{aCu}-\mathrm{Zr}, \mathrm{Cu}_{51} \mathrm{Zr}_{14}$ and $\mathrm{Cu}_{9} \mathrm{Zr}_{2}$ - were compared and the hardness of the textured $\mathrm{Zr}$ layers was shown to be highly anisotropic.

\section{ACKNOWLEDGMENTS}

The authors gratefully acknowledge the help of J. Furr, J. Schimmeyer and B. Viani. This work was performed under the auspices of the US Department of Energy by the Lawrence Livermore National Laboratory under contract \#W-7405-ENG-48.

\section{REFERENCES}

1) T. Foecke and D.S. Lashmore, Scripta Met., 27, 651 (1992).

2) K.K. Shih and D.B. Dove, Appl. Phys. Let., 61, 654 (1992).

3) P.B. Mirkarimi, L. Hultman and S.A. Barnett, Appl. Phys. Let., 57, 2654 (1990).

4) R.C. Cammarata, T.E. Schlesinger, C. Kim, S.B. Qadri and A.S. Edelstein, Appl. Phys. Lelt., 56, 1862 (1990).

5) C. R. Barnett, W.D. Nix and A.S. Tetelman, The Principles of Engineering Materials, pp. 318-20, Prentice-Hall, Inc., NJ (1973).

6) D. Tabor, The Hardness of Metals, Oxford (1951).

7) E.O. Hall, Proc Phys. Soc., Lond., B64, 747 (1951); N.J. Petch, J. Iron \& Steel, 174, 25 (1953).

8) J.S. Koehler, Phys. Rev. B, 2,547 (1970) and S.L. Lehoczky, Phys. Rev. Lett., 41, 1814 (1978).

9) G.E. Dieter, Mechanical Metallurgy, p. 37, McGraw-Hill, N.Y. (1976).

10) J.L Glimois, P. Forey and J.L. Feron, J. Less-Common Met., 113, 213 (1985).

11) W.L Johnson, Mater. Sci. Eng., 97, 1 (1988).

12) T.W. Barbee, Jr., R.G. Walmsley, A.F. Marshall, D.L. Keith, and D.A. Stevenson, Appl. Phys. Lell., 38, 132 (1981).

13) E. Kneller, Y. Khan, and U. Gorres, Z. Metallkd., 77, 43 (1986).

14) T.P. Weihs, T.W. Barbee, Jr., and M.A. Wall, Proceedings of Symposium O, "Phase Transformations in Thin Films," MRS Meeting, Spring 1993.

15) H. O'Neill, Hardness Measurements of Metals and Alloys, pp. 77-78, Chapman and Hall, LTD, UK (1967).

16) F. R. Moral, J. Metals, 10, 662 (1958).

17) A. Lawley and R. Maddin, Acta Met., 8, 275 (1960). 

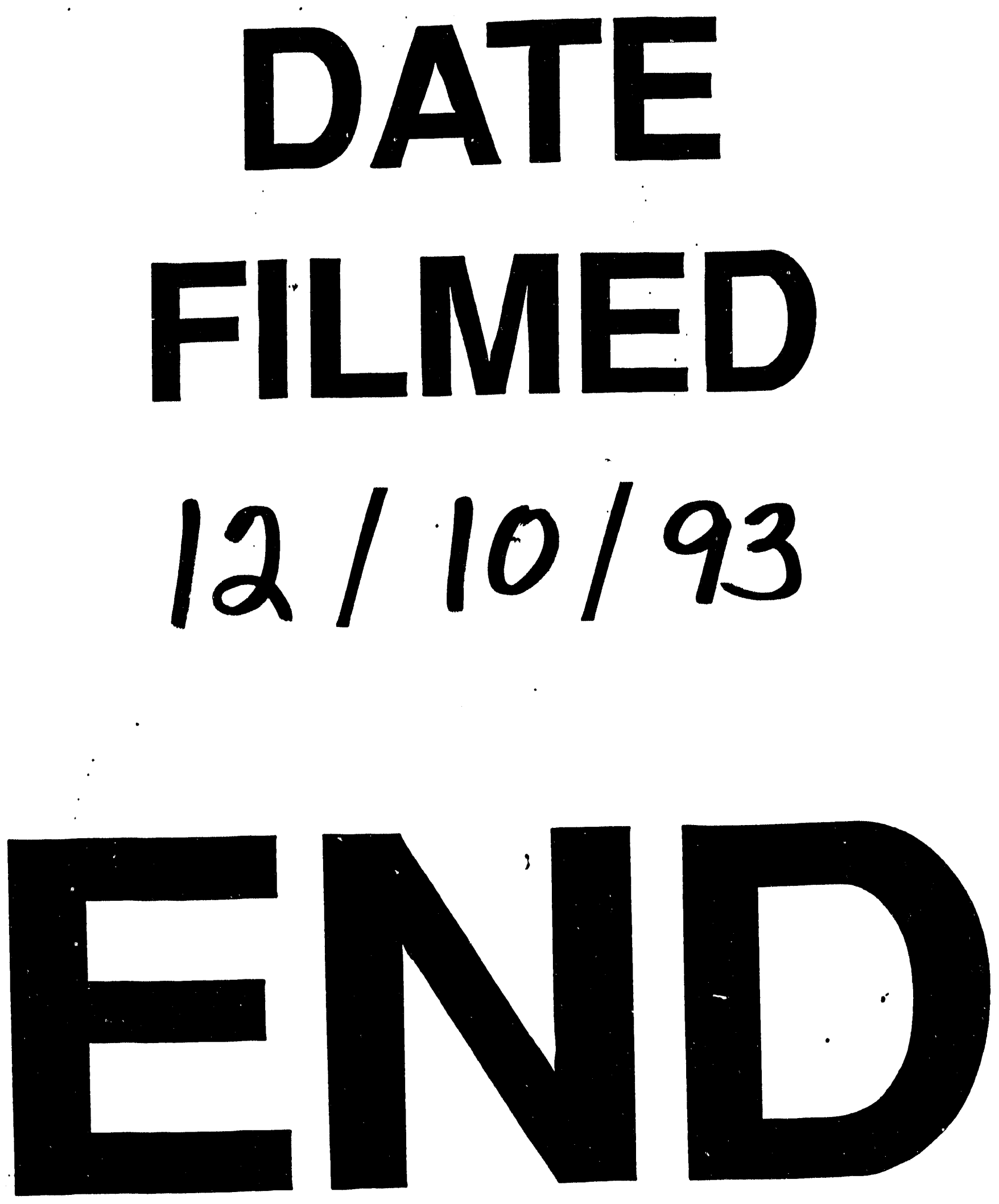
